\title{
On an Australian Specimen of Clepsydropsis.
}

\author{
BY \\ B. SAHNI, M.A. (Cantab.), M.Sc. (Lond.). \\ With Plate IV and two Figures in the Text.

\section{INTRODUCTION:}

THE specimen forming the subject of this paper is from the private I collection of Mr. A. B. Walkom, of the University of Brisbane. It was collected near $M t$. Tangorin, New South Wales (long. ${ }_{5} 5^{\circ}{ }_{22}^{\prime} E$., lat. $32^{\circ} 36^{\prime} \mathrm{S}$.), and, although not discovered in situ, is, according to the owner, probably of Carboniferous age. More definite information regarding the horizon is unfortunately lacking.

A cursory examination of the sections showed that the fossil should be referred to the Zygopterideae, and that on account of the shape of the petiolar trace (as seen in transverse section) it would have to be placed near Clepsydropsis antiqua, Unger. This fact had an additional interest at the time, for I was then under the impression that this was the first specimen of a $Z$ ygopterid to be recorded from Australia-in fact from any other part of the world except Europe and one locality in Western Siberia. The work was therefore carried on with increased interest : the greater part of it was completed early in the year I9I 7 , and a preliminary account was read before the Cambridge Philosophical Society on February 19, 1917. Only a few days before that date, however, I received from Professor W. H. Lang a letter for which I am much indebted to him. In that letter he informed me that Mrs. E. M. Osborn, of Adelaide, Australia, was also investigating a Zygopterid from Australia, and referred me to her preliminary account of it in the Annual Report of the last Manchester meeting of the British Association (I9J 5), ${ }^{1}$ of which I was unfortunately not aware. Mrs. Osborn's fossil also comes from New South Wales, but from a locality near Barraba, about i $5^{\circ}$ miles north-west of $\mathrm{Mt}$. Tangorin, and was discovered in situ in rocks probably of Upper Devonian age. From the short sketch just referred to it was obvious that the two plants belonged to the same genus, but it was impossible to say whether the Barraba fossil was.specifically distinct from

1 pp. $727-8$.

[Annals of Botany, Vol. XXXIII. No. CXX]X. January, 1919.]

G 
the Mt. Tangorin fossil. On the advice of Professor Seward a brief description of the Mt. Tangorin specimen, accompanied by a few rough figures, was sent to Mrs. Osborn for comparison; in her answer (received in September 1917) she states that there is no doubt as to the specific identity 'of the two, and proposes the name Ankyropteris australis (see, however, pp. 83-4, below). Two valuable features about the Barraba fossil are, firstly, that the stem is preserved, and, secondly, that the origin of the leaf-trace is visible. The Mt. Tangorin specimen, on the other hand, which does not include the stem, and is on the whole not well preserved, contains portions of the petioles slightly more distal than those in the Barraba fossil, and in the further branching of the petiolar trace to a very small extent appears to supplement the structures preserved in the latter.

I am very grateful to Mrs. Osborn for the great kindness she has shown me in comparing my description and in so willingly supplying me with unpublished details about her own fossil, which have been of much help and interest. It is also my pleasant duty to express my heart-felt thanks to Professor Seward, who was kind enough to entrust the work to me, and who has been a constant source of help and encouragement. The work was carried out during the tenure of a Research Studentship at Emmanuel College, Cambridge, and latterly also of a Grant from the Dixon Fund of the University of London.

\section{Review of Previous Literature.}

The name Clepsydropsis, which has reference to the cross-section of the petiolar trace, was first used by Unger in $1854,{ }^{1}$ but it was not until two years later ${ }^{2}$ that he published a diagnosis of the genus, placing it in Corda's ${ }^{3}$ family Rachiopterideae, and described (provisionally as three distinct species, $C$. antiqua, robusta, composita) some fern-petioles from the Cyprid Schists in the Upper Devonian (Lower Culm) of Saalfeld in Thuringia: Unger's originals have since been several times re-examined, and from Solms-Laubach's ${ }^{4}$ work (I896), as well as from a more recent paper ${ }^{5}$ by Dr. Paul Bertrand, it appears that the two last-named species were founded upon deformed specimens of $C$. antiqua, Ung. In 1889 . Stenzel ${ }^{6}$ described another species, Asterochlaena (Clepsydropsis) kirgisica, Stenz., from the vicinity of Pawlodar, north of Semipalatinsk in Western Siberia, about the horizon of which we have no certain data. The fossil was discovered as a pebble in an alluvium overlying coal-bearing strata, and was considered to be of Lower Permian (Rothliegende) age, ${ }^{7}$ but this is by no means free from doubt. ${ }^{8}$.The original of Stenzel's Fig. $3^{8}, \mathrm{Pl}$. IV, collected by Åberg

\footnotetext{
1 Unger (1854), p. 599.

s. Corda (1845).

b Bertrand (1911 a), p. 4 .

7 Stenzel (1889), p. 20.

- Solms (1910), p. 542. See also Goeppert u. Stenzel (1881); p. 16.

Unger (1850), p. $16_{5}$.

4 Solms (1896), pp. $2 j-7$.

- Stenzel (1889).
} 
and conveyed to Germany by Ludwig, was at Dresden, but Stenzel also examined a slice in the possession of Goeppert. ${ }^{1}$

Hitherto two species, namely, $C$. antiqua, Ung., from the Upper Devonian of Thuringia, and C. kirgisica, Stenz., doubtfully from the Lower Permian of West Siberia, have been recognized. The published descriptions do not reveal any differences that are clearly of specific value, but, pending a more detailed examination of Stenzel's fossil, it is prudent to keep the two species apart.

The most recent paper directly bearing upon the subject is Mrs. Osborn's 'Preliminary Observations on an Australian Zygopteris', ${ }^{2}$ which is of great interest as being the first record of the $Z$ ygopterideae from outside of Europe and Siberia. In this paper two important points, on which there has been a good deal of speculation in the past, ${ }^{3}$ have been definitely settled. Firstly it has been shown that the cauline xylem cylinder is of the Ankyropteris Grayi type, and secondly that the leaf-trace is nipped off as a closed ring of xylem enclosing a portion 'of the 'mixed pith' of the stellate axial cylinder, and that this ring subsequently becomes flattened, with a slight curve convex on the adaxial side (as is often the case in Ankyropteris). The curve finally disappears, and a slight median constriction imparts to the trace the form well known for the genus Clepsydropsis (see Text-fig. 2, I). There are no axillary branches.

\section{Nomenclature.}

As already mentioned, Mrs. Osborn has proposed to place the fossil in the genus Ankyropteris, a perfectly natural course, considering the stem structure and the mode of origin of the leaf-trace. On the other hand, the shape finally assumed by the leaf-trace would by itself lead to a reference of the plant to the genus Clepsydropsis. In fact the latter course was at first actually adopted in the case of the Mt. Tangorin specimen, described below, in which the stem and the leaf-trace origin are not preserved. However, the combination, in the Barraba specimen, of the structural

1 In the same year Schenk (1889, pp. 553-4; see also Schenk, 1890, pp. 46, 156) figured and briefly described a fossil (Rachiopleris Ludwigii, Leuckart u. Schenk) mainly agreeing with Stenzel's description of $C$. kirgisica. The original of Schenk's outline drawings (PI. JII, Figs. 50, 5I) was in the Botanical Collection at Leipzig and was named by him after Ludwig, who collected it in the Ural steppes between Akolinsk and Semipalatinsk, and Leuckart, through whose agency it reached Leipzig. The ultimate sources of the two originals are so nearly identical as to leave little doubt that they were portions of the same specimen, yet neither Stenzel nor Schenk refers to the other's paper; on the contrary, both the authors seem to imply that their respective fossils were till then undescribed. There is on this point a regrettable confusion in the.literature, which, in spite of Solms-Laubach's $(1910$, p. 543) attempt to explain it, appears not yet to have been removed. Only C. kirgisica, Stenz., has been recognized by subsequent writers, although it is possible that C. (Rachiopt.) Ludzvigii, Leuck. u. Schenk, may be distinct, for Schenk's figures of the transverse sections show the petiolar trace in this fossil at least half as long as the petiolar diameter.

2 Osborn (1915), pp. 727-8.

3 Bertrand (1908, 1911 b, $1911 c, 1912,1914)$; Solms (1910), Pp. 540-I. 
features of both Clepsydropsis and Ankyropteris strongly suggests that these two genera should be united. This step was proposed in a recent paper, ${ }^{1}$ and in the following pages the genus Clepsydropsis will be understood to include Ankyropteris.

It is of some interest to find that this conclusion is fully corroborated by some photographs of $C$. antiqua, Ung., published by Dr. P. Bertrand in I9II (1911 $a$, Pl. II, Fig. I6 ; Pl. I, Figs. I, $2+3$ and $4+5$; also Bertrand, 1912, Fig. 21, p. 228). These figures show beyond doubt that the mode of leaf-trace origin in that species was essentially the same as that in the Barraba fossil, and that known for $C$. (Ank.) Grayi, Will., if we disregard the complications due to the presence of the axillary branch. (See Fig. 35, p. 244, in Progressus, 1912.)

The figures in question are based upon a single specimen, discovered by Dr. Bertrand among Unger's originals. The unusually small dimensions of the petiolar strand led him to conclude that it was probably either an abnormally thin petiole or a normal petiole sectioned in its distal region. Dr. Bertrand, however, evidently overlooked one rather important point in the figure, which shows that it undoubtedly represents a section across the basal region of a petiole. This is the presence, in the tangential plane, of a plate of narrow tracheides forming a bridge between the two peripheral loops and similar to the tracheides lining the loops themselves. The significance of this feature at once becomes apparent when we consider that the clepsydroid shape of the strand in the Barraba fossil is the result of the tangential flattening, followed by a median constriction, of a closed xylem ring lined internally by a zone of specially narrow tracheides. An exactly similar condition was observed in one of the petiolar strands in the Mt. Tangorin specimen, and is described below (p. 88; see Fig. 6, Pl. IV). Subsequently I learned from Mrs. Osborn that the same feature is visible in her specimen, and that it persists for a short distance from the leaf-base upwards.

A diagnosis of the genus Clepsydropsis as extended in accordance with the above suggestion is given in my paper above referred to, along with other theoretical considerations.

\section{DEscription.}

Gross features. When received the fossil was an almost semicircular slab about $3.5 \mathrm{~cm}$. thick, with the diameter of the semicircle about $11 \mathrm{~cm}$. long. The more or less flat upper and lower faces showed the cut ends of about a dozen cylindrical petioles varying in diameter from about 15 to $17 \mathrm{~mm}$., a few of which were evidently compressed into unnatural shapes. The spaces between the petioles were packed with numerous occasionally branched roots running in all directions. These were possibly mixed with

1 Sahni (1918). 
Sahni.-On an Australian Specimen of Clepsydropsis. $85^{\circ}$

pinnae and aphlebiae; though these could not definitely be made out. On the polished faces the characteristic petiolar strands could be observed in several of the leaves, and when the surface was covered with a thin layer of oil, with the help of a lens the course of the roots and petiolar strands could be traced for some distance into the transparent siliceous matrix.

Text-fig. I is a diagram to show the fossil in plan and elevation; the outlines of the plan were drawn from the lower end of the fossil. The block was first cut into two pieces along $\mathrm{xx}$, and from the left-hand piece

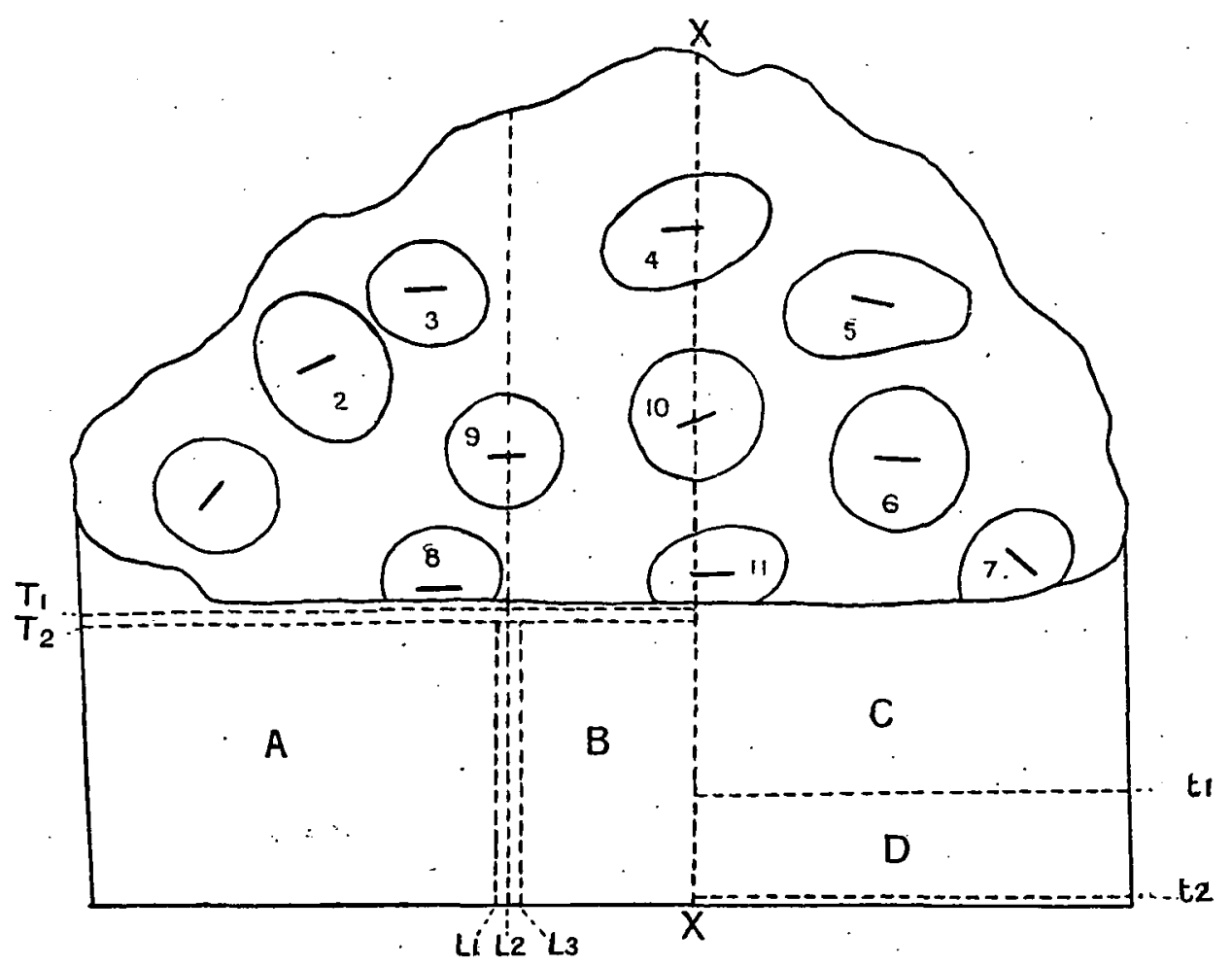

Texr-fig. I. Diagram. For explanation, see text.

the two transverse sections $\mathrm{T} I, T 2$, and the three longitudinal sections $\mathrm{L}$, $\mathrm{L} 2, \mathrm{~L} 3$ were prepared. Subsequently two transverse sections $t \mathrm{I}, t_{2}$ were prepared from the right-hand piece. The original specimen is therefore now in four pieces, A, B, C, D, besides a fragment left over after levelling one of the ends. In the figure the petioles are marked with numbers to correspond with those in Text-fig. 2.

The orientation of the petiolar strands (indicated by short straight lines in Text-fig. 1) shows that the leaves are arranged in their natural positions round a stem which is, however, missing. The longitudinal sections show the petioles sloping inwards towards the stem side, but from the low angle 
at which they stand to the vertical it may be concluded that the leaves were probably almost erect in their basal region. These facts make it very probable that the plant was a fair-sized tree-fern resembling the fossil Osmundaceae.

Anatomy. The preservation on the whole cannot be described as good, although some portions show well-preserved details of structure. Many of the roots have penetrated deep into the cortex of the leaf-stalks, and have even distorted the shapes of most of the petiolar strands.

The roots probably all belong to the Clepsydropsis itself, although none of them is seen actually connected with the leaves - they may be arising from the more proximal regions of the latter and in part even directly from the stem, as appears to be the case in the Barraba specimen, and as Stenzel (1889) describes in $C$. kirgisica (p. 22, Pl. IV, Fig. 38, w'). They have a diarch xylem strand (Pl. IV, Fig. I) and the pitting of the metaxylem tracheides was finely scalariform as in the leaf-strand. The cortex of the petiole consists of a broad inner zone of large thin-walled cells with interspaces, succeeded on the outside by a narrower zone of cells gradually decreasing in diameter towards the epidermis (PI. IV, Fig. 2). In longitudinal section the cells of the inner cortex are nearly isodiametric, those of the outer cortex more elongated, with transverse or oblique end-walls (Pl. IV, Fig. 3). The epidermis is not preserved, consequently the 'external glands or hairs' mentioned by Mrs. Osborn are not seen. A few of the outermost layers of the cortex appear to be specialized as a thickened hypodermis, as described by Schenk in Rachiopteris Ludwigii (1889, p. 554), but it is difficult to be clear on this point. The total radial thickness of the preserved cortex varies from 3 to $4 \mathrm{~mm}$.; between it and the petiolar strand the leaf tissues are nowhere preserved. In Schenk's fossil just referred to this space was in part at least (loc. cit., p. 553) occupied by a sclerotic sheath.

The adjoining figures, from camera-lucida sketches of the petiolar strands, illustrate the extent to which the intruded roots (shown in rough outline only to indicate their positions) distort the normal clepsydroid shape of the leaf-traces. Only one of these happens to be completely undisturbed (Text-fig. 2, I, I). It was seen cut at two different levels (T $\mathrm{I}$, T 2) and its dimensions are given below :

Total length, $6 \cdot 4 \mathrm{~mm}$.

Thickness at the "waist', $3 \mathrm{~mm}$.

Lẹngth of each peripheral loop, $1 \cdot 7 \mathrm{~mm}$.

Distance between the inner ends of the two loops, $2 \cdot 1 \mathrm{~mm}$.

The variations in size could be judged from the remaining figures, but the amount of distortion makes it unsafe to base any measurements upon them. The limits of the xylem could not in all cases be accurately observed, owing to imperfect preservation. In many places only rows of dirt-granules are seen, which, however, unmistakably marked the contours 
I, I.

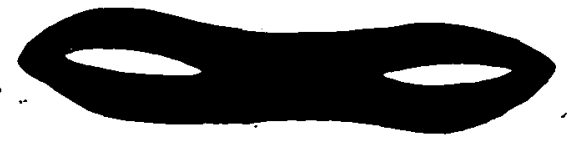

2.

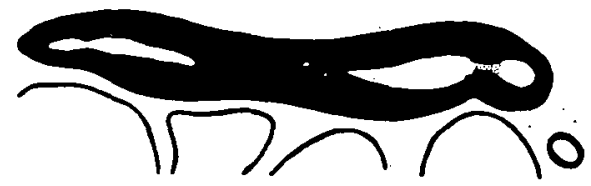

3.
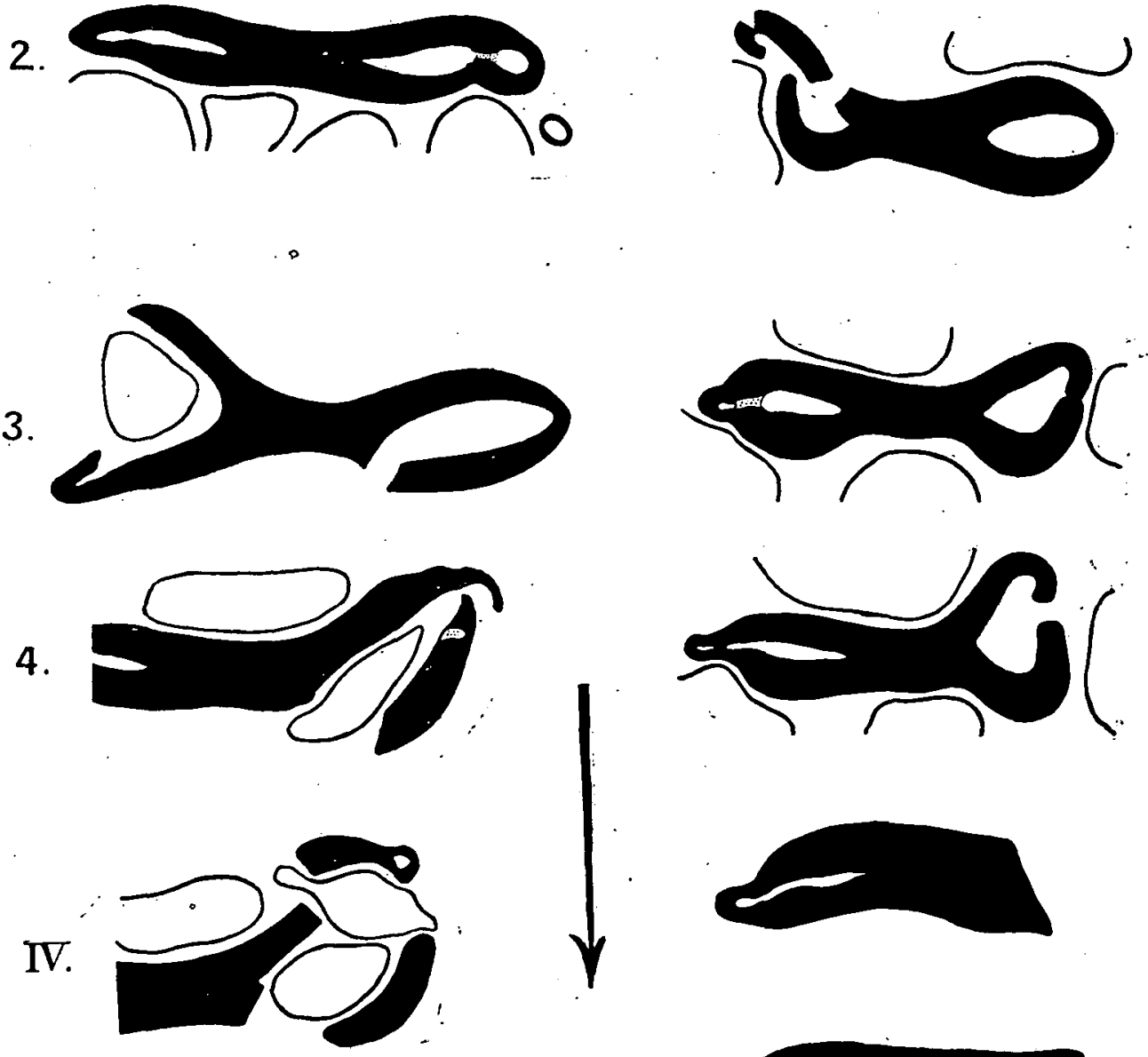

VII.

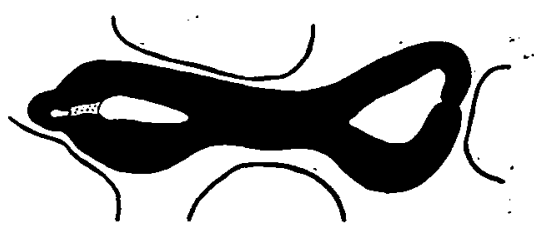

9
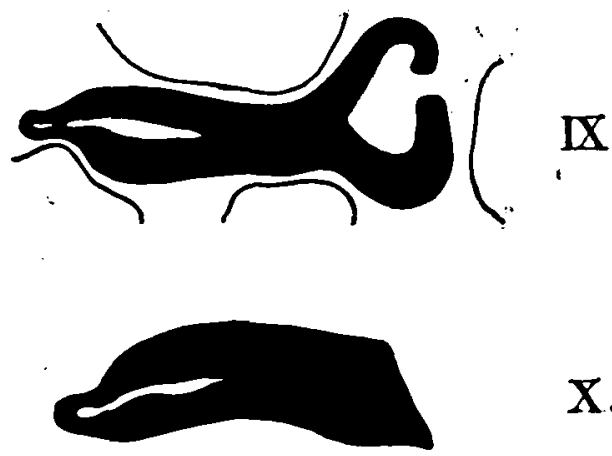

$\mathrm{X}$.
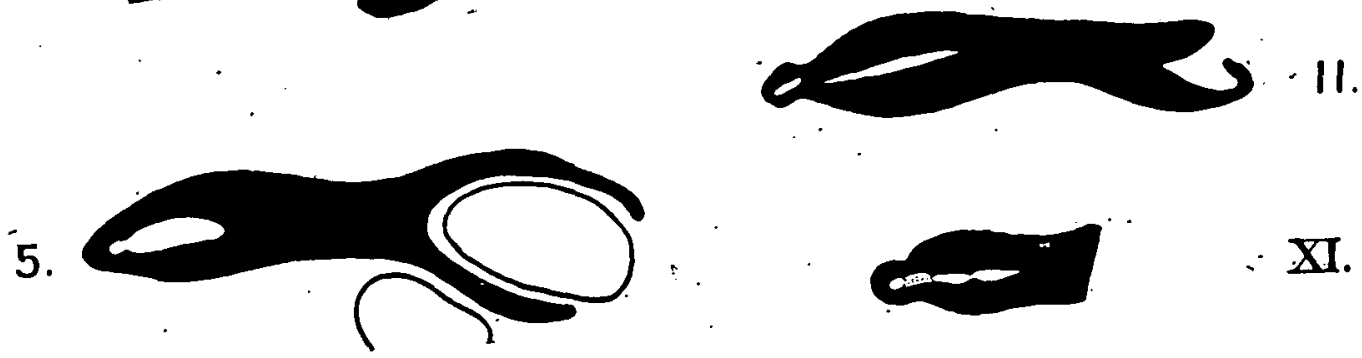

$\therefore$ XI.

TEXT-FIG. 2. The petiolar strands, which are all shown with their adaxial faces in the direction of the arrow, are marked with numbers to correspond with those in Text-fig. I. The Roman numerals refer to the petioles as seen in the transverse sections $\mathrm{T} 2, t 2$; the corresponding Arabic numerals to the respective petioles, as seen in the transverse sections $T 1, l i$. For further explanation, see text, p. 86. 
of the tracheides. Only those parts are shown in solid black where outlines of tracheides were recognized with tolerable certainty. The dotted areas refer to parts where the existence of xylem was only inferred.

The shape of the trace at once decides the specific distinctness of the plant from either C. antiqua, Ung., or C. kirgisica, Stenz. It is proportionately thinner, has pointed instead of truncated ends, and the internal contour of the peripheral loops is fusiform instead of elliptical.

The tissue filling the peripheral loops, which in the Barraba fossil consists of parenchyma intermixed with small tracheides, is not preserved at all. The loops are instead filled up by a deposit of mineral granules in the form of peculiar branched tubular structures, the appearance of which suggests that they were probably formed in the same manner as a continually growing semi-permeable membrane round a crystal of copper sulphate in a solution of potassium ferrocyanide. A similar process was probably responsible for a pseudo-cellular structure replacing the cortical cells in some of the leaves, each pseudo-cell having been formed round an independent centre.

The tracheides are practically all scalariform (Pl. IV, Fig. 4), with occasional anastomoses between the bars of thickening, as an approach to the reticulate type. The peripheral loops are lined with tracheides distinctly narrower than those immediately outside them. As we pass still farther away from the loops the tracheides again diminish in size (Pl. IV, Fig. 5). Only one spiral element was observed; of the others some on account of their small diameter gave the impression of being annular. In a few scalariform tracheides the pits, which were rather farther apart than usual, showed in surface view what may be called 'false borders', because in sectional views they could not be seen at all. It may be that the free edges of the thickening bars, instead of hanging over the pit so as to narrow the entrance to it, sloped in the opposite direction, so that the entrance to the pit became wider than the bottom. The effect in surface view would in either case be almost the same. The tracheides average about $100 \mu$ in diameter; the largest seen was $180 \mu$, the smallest $20 \mu$ across.

In one of the leaf-traces the inner ends of the two peripheral loops were connected by a series of narrower tracheides similar in size and form of pitting to those lining the loops themselves (Pl. IV, Figs. 6, 7). The significance of this feature has already been explained on p. $\mathbf{8 4}$.

Dr. Bertrand (1911 c, p. 509) records the presence in the leaf-strand of $C$. antiqua of a number of tracheides of secondary origin. No trace of secondary xylem was present in any of the leaf-strands of the Mt. Tangorin fossil.

The origin of the pinna-trace is exactly as in $C$. antiqua, that is, the trace is constricted off as a closed ring from the end of the peripheral loop. Unfortunately the large number of intrusions have greatly disturbed the 
relative positions and shapes of the different parts of the xylem, and in a few cases (Text-fig. 2) they have even broken the latter into two or more pieces.

One of the leaves shows further branching of the vascular supply (Text-fig. 2, 2). In this case a small elliptical ring of xylem is seen lying just off the pinna-trace, adaxially to it, at an angle of $4 j^{\circ}$. Owing to bad preservation, in the only other section that passes through this leaf there is no sign of this strand, so that it is at present impossible to ascertain its point of origin, whether from the pinna-trace or directly from the primary leaf-strand; but from the direction of the long axis of the ellipse (due to oblique section of a circular tube) it seems highly probable that it arose from the pinna-trace. In view of the proximity of intruded roots, however, it is quite likely that the strand in question has been shifted slightly out of its natural position. The obliquely-cut tracheides show a finely scalariform pitting; no spiral or annular elements are seen. The thickness of the ring is about three tracheides; the tissue in the centre of the ring is not preserved.

\section{THEORETICAL.}

Apllebiae. In C. antiqua Dr. Bertrand (1911 a, pp. $\left.{ }^{1} 5^{-1} 7\right)$ has figured a small ring-like strand occupying a rather similar position. This strand evidently has the same morphological value in both cases. Dr. Bertrand regards it as the trace of a pinnule (tertiary rachis). It is probable, as Professor Seward suggested, that the organs supplied by these tertiary strands were of the nature of aphlebiae. This supposition is confirmed by a comparison with the corresponding structures in Diplolabis Roemeri, Metaclepsydropsis duplex (Gordon, $1911 \cdot a, b$ ), Stauropteris oldhamia (Bertrand, 1909, p. 29, Fig. 4). The strands referred to by Stenzel (1889, p. 45) as arising from the base of the leaf-trace are also probably of the same nature.

Better preserved material is necessary to decide the question as to the normal number and position of the aphlebia-strands on each side of the pinna in Clepsydropsis (Unger, 1856, p. 167 ; Solms, 1896, pp. 25-7 ; Stenzel, 1889, pp. 2I, 23); a re-examination of Stenzel's original specimens of C. kirgisica would be useful.

Habit.-The known genera of Zygopterideae may be classified into two groups, the Clepsydroideae (including the genera Asterochlaena and Clepsy. dropsis) and the Dineuroideae (including Dineuron, Diplolabis, Metaclepsydropsis, Etapteris, Stauropteris, Zygopteris, and provisionally Gyropteris sinuosa, which may ultimately have to be placed as a species of either Diplolabis or Metaclepsydropsis). Except for Gyropteris, these two groups are co-extensive with those proposed by Kidston and Gwynne-Vaughan $(1910$, p. 470) on the basis of the number of (free) branch-axes on each side 
of the primary rachis. It is interesting to find that, so far as our present knowledge goes, the symmetry of the stem in the two groups is quite distinct. Thus in the only genera of the Dineuroideae in which the stem is known, viz. Diplolabis and Metaclepsydropsis (Gordon, $1911 a, b$ ), it had the form of a creeping rhizome with the leaves confined to the dorsal side and rising perpendicularly from it. On the other hand, in the Clepsydroideae, in which our knowledge of the stem is more complete, the leaves arose radially on all sides of the stem, which was either an upright stock (Asterochlaena (Bertrand, 1911 b), C. kirgisica (Stenzel, 1889, Fig. 38, Pl. IV), and the Australian Clepsydropsis) or, as in $C$. (Ank.) scandens (Stenzel, 1889; Scott, 1909), it scrambled among the roots on the upright stem of a Psaronizs.

It appears as if the precocious bifurcation of the pinna-trace in the Dineuroideae (except Gyropteris), and the consequent peculiar habit of the petiole in that sub-family, had something to do with the manner in which the basal portion of the leaf was held. One is tempted to expect that the stem of the remaining Dineuroideae will also be a horizontally creeping rhizome.

\section{Summary.}

A description is here given of a Clepsydropsis, collected near Mt. Tangorin, New South Wales, in rocks possibly of Carboniferous age. It is specifically identical with the fossil briefly described by Mrs. Osborn in the Report of the British Association*(Manchester meeting, 1915, p. 727).

It is shown that in $C$. antiqua, Unger, also, the leaf-trace arose as a closed ring of xylem which became tangentially flattened, and then became clepsydroid as the result of a median constriction. This fact strongly supports the suggestion put forward in an earlier paper that the genera Clepsydropsis and Ankyropteris should be united, the leaf-trace origin in the latter genus being known to be essentially the same.

The two groups of the Zygopterideae (Clepsydroideae and Dineuroideae) were also sharply distinct in the symmetry of their stem, which, so

en/ far as we know, was radial in the formel group and dorsiventral in the latter. It is suggested that this distinction will be maintained as our knowledge of the stem becomes more complete. The apparently radial symmetry of the basal region of the leaf in the Dineuroideae (due, as previously shown, to an early bifurcation of the pinna-trace) may also be related to its probably strictly upright position in that sub-family. The opinion has already been expressed in an earlier paper that this apparently radial symmetry was not continued into the probably more or less horizontal laminated distal portion of the leaf.

Botany School, Cambridge, April I, 1918. 


\section{BIBLIOGRAPHY.}

Bertrand, Paul (1908): Sur les stipes des Clepsydropsis. Comptes Rendus, cxlvii, pp. 945-7. (1909): Études sur la fronde des Zygoptéridées. Lille.

- $(1911$ a) : Nouvelles remarques sur la fronde des Zygoptéridées. Bull. Soc. Hist. Nat. Autun, xxv.

t. vii, mém. No. 1 .

(191:16): Structure des stipes d'Ásterochlaena laxa. . Mém. Soc. Géol. du Nord,

(1911c): Observations sur les Cladoxylées. Assoc. Franç. pour l'Avancement des Sciences, $40^{\circ}$ session, Dijon, p. 509.

(1912): L'étude anatomique des fougères, etc. Progressus rei botanicae, iv.

(1914): État actuel de nos connaissances sur les genres Cladoxylon et Steloxylon.

Assoc. Franç. pour l'Avancement des Sciences, $43^{\circ}$ session, Le Havre, p. 446.

CORDA (1845): Beiträge zur Flora der Vorwelt. Prag.

Gozpper'T, H. R., und Stenzel, G. (1881): Die Medulloseae, eine neue Grappe der fossilen Cycadeae. Palaeontographica, 28 (3. Folge, 4. Lief, iii), p. 16.

Gornon, W. T. (191 I a): On Diplolabis Roemeri Solms. Trans. Roy. Soc. Edin., xlvii, Part IV, No. 24 .

$(19116)$ : On Melaclepsydropsis duclex Will. Ibid., xlviii, Part I, No. 8.

Kinston, R., and Gwynne-Vaughan, D. T. (1910): On the Fossil Osmundaceae. Part IV, ibid.

Osborn, E. M., Mrs. (1915): Preliminary Observations on an Australian Zjgopleris. Report British Assoc., pp. 727-8.

SahNi, B. (1918): On the Branching of the Zygopteridean Leaf and its Relation to the Probable 'Pinna' Nature of Gyropleris sinuosa Goeppert. Annals of Botany, xxxii.

Schenk, A. (1889): Ueber Medullosa, Cotta, und Tubicaulis, Cotta. Abh. d. kgl. sächs. Ges. d. Wiss., xxvi, Math..Phys. Kl., xv.

(1890): Die fossilen Pflanzenreste. Handbuch der Botanik, iv. Breslau.

ScorT, D. H. (1909): Studies in Fossil Botany.

(1912): On a Palaeozoic Fern, the Zygopleris Grayi of Williamson. Annals of Botany, xxvi (i), p. 39.

Solms-LaUbach, H., Graf zU (1896): Ueber die seinerzeit von Unger beschriebenen .. . Pflanzenreste ... von Saalfeld.... Abh. d. k. preuss. geol. Landesanstalt, Nene Folge, Heft 23, Merlin.

(1910): Ueber die in den Kaiksteinen des Kulm von GlaetzischFalkenberg in Schlesien erhaltenen struktubietenden Pflanzenreste, IV. Zeitschrift für Botanik.

Stenzel, G. (1889): Die Gattung Tubicaulis, Cotta. Bibliotheca Botanica, Heft I2, Cassel.

UNGer, F. (1854): Zur Flora des Cypridinenschiefers. Sitzungsber. d. k.-k. Akad. Wiss. Wien, Bd. xii, p. 599.

(1856): Beitrag zur Paläontologie des Thüringer Waldes (Richter u. Unger). Denkschr. d. k.-k. Akad. za Wien, Math.-Naturwiss, K1., xi, p. $16_{5}$.

\section{EXPLANATION OF PLATE IV.}

Illustrating Mr. Sahni's paper on an Australian Specimen of Clepsydropsis.

(The figures are all from untouched photographs, with the exception of Fig. 3, in which some of the fainter lines on the print.were intensified with a lead pencili)

Fig. I. Transverse section of a diarch root-strand; the two poles lie at the right and left ends of the strand. $x$ c. 35.5.

Fig. 2. Transverse section of peripheral region of a petiole. o.c., outer cortex; i.c., inner cortex. $\times c .38$. 


\section{Sahni.-On an Australian Specimen of Clepsydropsis.}

Fig. 3. Longitudinal section of the same. $\times c .43$.

Fig. 4. Longitudinal section of a portion of a petiolar strand, to show the finely scalariform pitting of the tracheides. $\times$ c. I 33 .

Fig. 5. Transverse section of a portion of the petiolar strand, also shown in Text-fig. 2, 3 . Owing to a fracture in the xylem, the peripheral loop appears considerably wider than is normally the case (compare with the undisturbed strand shown in -Text-fig. 2). : The loop is lined internally as well as externally by specially narrow. tracheides. $x c .40$.

Fig. 6. Transverse section of the petiolar strand, also shown in Text-fig. 2, g. a., a., antennae; p.l., peripheral loops; s.t., small tracheides, forming a more or less complete bridge between the two loops $\times$ c. 29.

Fig. 7. Longitudinal section of the same strand, passing radially across its median plate, to show the small tracheides; s.t., flanked by the larger tracheides. $\times c .33$. 


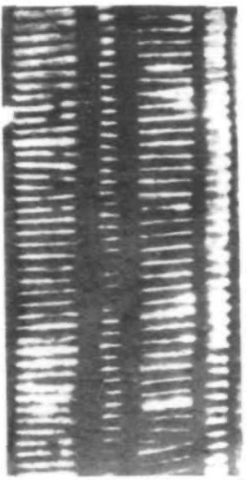

4.

2

1.

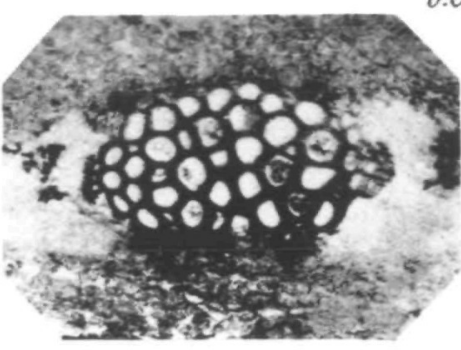

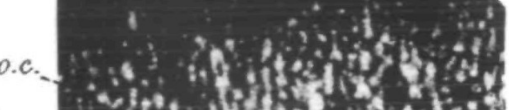

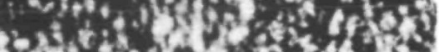

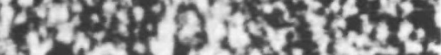

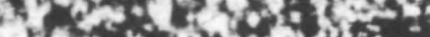

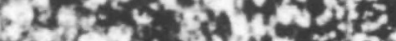

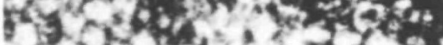

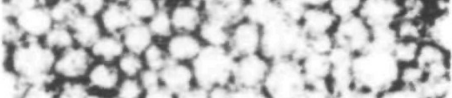

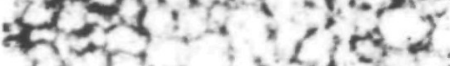

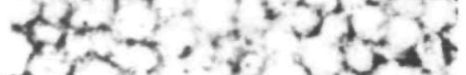

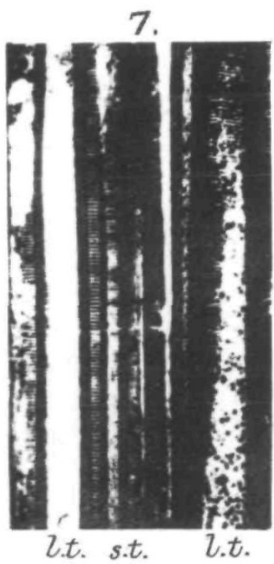

6.
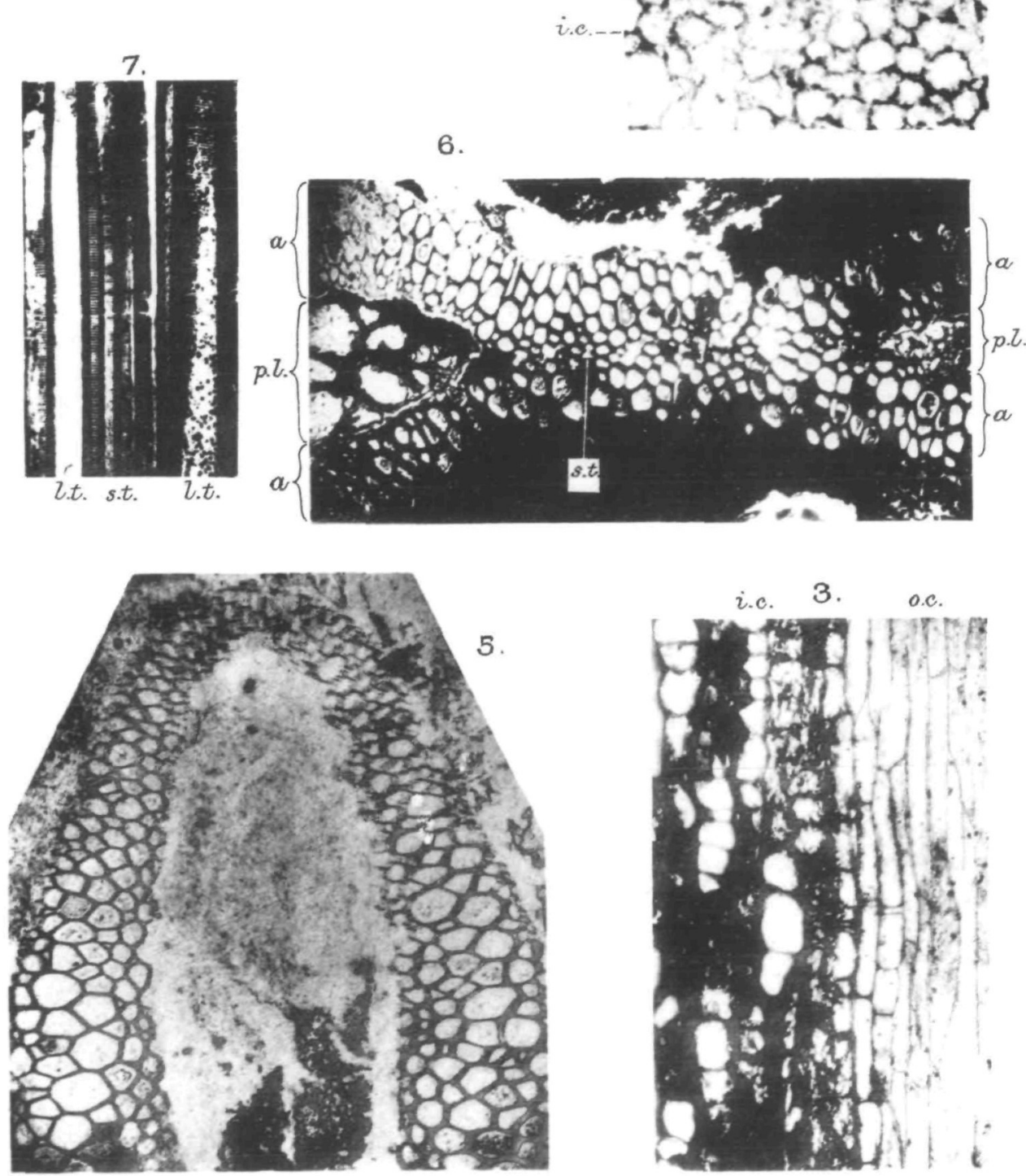

B. Sahni phot. 
